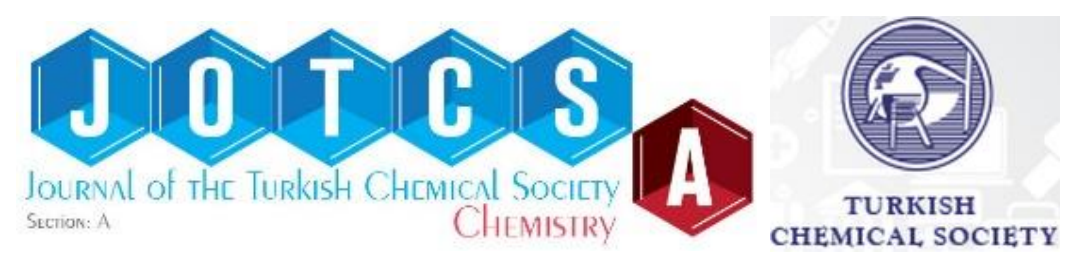

\title{
Some Heavy Metal Contents of Various Slaughtered Cattle Tissues in Sivas-Turkey
}

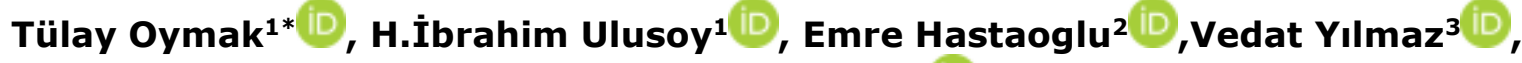 \\ and Şahin Yıldırım ${ }^{4}$
}

\begin{abstract}
${ }^{1}$ Cumhuriyet University, Faculty of Pharmacy, Department of Analytical Chemistry, 58140, Sivas, Turkey

${ }^{2}$ Cumhuriyet University, Yildizeli Vocational School, Department of Food

Technology,58140, Sivas, Turkey

${ }^{3}$ Erciyes University, Faculty of Pharmacy, Department of Analytical Chemistry, 38030, Kayseri Turkey

${ }^{4}$ Cumhuriyet University, Faculty of Medicine, Department of Pharmacology,58140, Sivas, Turkey
\end{abstract}

\begin{abstract}
As a result of environmental pollution and food chain, heavy metals may accumulate in human or animal bodies. Toxic metals cause inhibition on chemical and enzyme reactions in cells. Therefore, a negative situation forms in organs and tissues due to their toxic effects. The examination of metal pollution in foods and environment facilitates to monitor their harmful effects on human health. In the proposed study, the concentrations of toxic metals in tissue samples of animal obtained from a local farm were analyzed by Inductively Coupled Plasma Mass Spectrometry (ICP-MS) following microwave digestion. Five different tissue samples were studied including lung, liver, kidney, muscle, and brain. Metals were showed various distribution in the different organs. The highest concentration of $\mathrm{Al}$ in the lung, $\mathrm{Cu}, \mathrm{Mn}$, and $\mathrm{Mo}$ in the liver $\mathrm{Cr}$, As and $\mathrm{Se}$ in kidney, and $\mathrm{V}$ in kidney and brain were found. The mean values obtained for kidney, liver, lung, muscle and brain of cattle tissues were: $2.40,2.44,3.73,2,90,3.07 \mathrm{mg} / \mathrm{kg} \mathrm{Al} ; 0.35,0.26$, $0.29,0.27,0.36 \mathrm{mg} / \mathrm{kg} \mathrm{V} ; 3.95,7.00,0.76,0.45,1.19 \mathrm{mg} / \mathrm{kg} \mathrm{Mn} ; 15.82,280.86,7.94$, $3.85,10.64 \mathrm{mg} / \mathrm{kg} \mathrm{Cu} ; 1.87,4.25,1.19,0.15,0.28 \mathrm{Mo} ; 0.47,0.14,0.10,0.07,0.04$ $\mathrm{mg} / \mathrm{kg} \mathrm{As} ; 0.47,0.33,0.41,0.39,0.43 \mathrm{mg} / \mathrm{kg} \mathrm{Cr} ; 4.38,1.38,0.82,0.60,0.56 \mathrm{mg} / \mathrm{kg} \mathrm{Se}$ respectively. Certified reference material (NIST CRM 2976 muscle tissue) was analyzed for accuracy of method. This results are good agreement ( $\geq 95 \%)$ with the certified values.
\end{abstract}

Keywords: Accumulation of heavy metals, Cattle tissue, ICP-MS.

Submitted: February 16, 2017. Accepted: May 16, 2017.

Cite this: Oymak T, Ulusoy H, Hastaoğlu E, Yılmaz V, Yıldırım Ş. Some Heavy Metal Contents of Various Slaughtered Cattle Tissues in Sivas-Turkey. JOTCSA. 2017 Jul;4(3):737-46.

DOI: http://doi.org/10.18596/jotcsa.292601.

*Corresponding author. . E-mail: tulayoymak@cumhuriyet.edu.tr Tel. : +90346219 1260 -3929 Fax : +903462191634. 


\section{INTRODUCTION}

In fact, the heavy metal term is used as a physical property of the metals whose density is greater than $5 \mathrm{~g} / \mathrm{cm}^{3}$. Heavy metals are classified as vital and non-vital metals according to their degree of participating to biological activities (1). Those that are defined as essential should be present in the organism at certain concentrations. In addition, since they participate biological reactions, these metals should regularly be taken through food (2). For example, copper is an indispensable part of red blood cells, as well as many oxidation and reduction reactions in humans and animals. However, it should be noted that high amount of heavy metals is toxic. On the other hand, non-essential heavy metals ( $\mathrm{Pb}, \mathrm{Cd}$, $\mathrm{Hg}$, etc.) may cause health problems by damaging biologic structure even at the lowest concentrations (3-4). Heavy metals have a risk potential for ecologic system and human health because, unlike organic polluter, they are not degraded, and they are accumulated in the food chain. Heavy metal pollution is one of the significant ecologic problems in many rapidly developing countries (5-7).

Animals and humans take heavy metals released into the air from industrial activities through inhalation, in addition, they join the food chain when reaching the earth. Heavy metals, may also have harmful effects on living organisms through wastewater mixed in drinking water or through the pollination of the particles contaminated with heavy metals $(8-15)$.

Heavy metals that animals orally get from their forage and water, or they receive from their surroundings accumulate in the tissue of their organs, such as liver, kidney, which is widely consumed by humans as a source of animal protein in the overall world. Consumers have no knowledge of the quantity of the heavy metal in the content of these products and the risk they carry for the health $(16,17)$. Therefore, monitoring the heavy metal concentration present in the tissues of this organ is significant regarding the control of the biochemical processes and ecosystem. In addition, heavy metal content in organisms provides insight into the risk of environmental pollution (18-21).

This study was evaluated the concentrations of some heavy metals in the kidney, liver, lung, muscle, and brain of slaughtered cattle from Sivas, Turkey 


\section{MATERIALS AND METHODS}

Trace metal grade reagents were used. Multi-element standard solutions were purchased from BDH Chemicals. A certified reference material (muscle tissue) was used to check the accuracy of the method.

\section{Instrumentation}

Studies were carried out by using a Thermo Scientific ICAP-Q ICP-MS instrument. The instrument was equipped with PFA-ST MicroFlow nebulizer and cyclonic quartz spray chamber offering exceptional sensitivity for analysis of samples with small volumes. Microwave Digestion System (CEM MARS 6) was used for digestion tissue samples. ICPMS operating conditions summarized in Table 1.

Table 1: ICP-MS operating conditions.

\begin{tabular}{|c|c|}
\hline RF power $(k W)$ & 1.55 \\
\hline Nebulizer & PFA-ST MicroFlow Nebulizer \\
\hline Spray chamber & Cyclonic Quartz \\
\hline Plasma Ar (L min $\left.{ }^{-1}\right)$ & 14 \\
\hline Auxiliary $\operatorname{Ar}\left(\mathrm{L} \mathrm{min}^{-1}\right)$ & 0.80 \\
\hline Nebulizer $\operatorname{Ar}\left(L \min ^{-1}\right)$ & 1.0 \\
\hline Sample uptake/mL min $^{-1}$ & 0.5 \\
\hline Scanning mode & Peak hopping \\
\hline Dwell time (s) & 0.01 \\
\hline
\end{tabular}

\section{Sampling}

Tissues of cattle organs were collected from one of the biggest farms in Sivas. The animals used in the study were two years old and healthy. Fifteen animals were studied as sample throughout a year. All samples were kept in plastic bags and immediately transported to the laboratory. The samples were washed with deionized water, cut into small pieces, and dried at $60^{\circ} \mathrm{C}$. Then, they were homogenized and stored at $4^{\circ} \mathrm{C}$ until analysis.

\section{Microwave Assisted Digestion Procedures}

Microwave vessels (PTFE) were cleaned using $10 \mathrm{~mL}$ of concentrated $\mathrm{HNO}_{3}$, heated for 15 min at $180^{\circ} \mathrm{C}(800 \mathrm{~W})$, and then rinsed with ultrapure water heated for $15 \mathrm{~min}$ at $180^{\circ} \mathrm{C}$ before each digestion. All samples were accurately weighted as $0.50 \mathrm{~g}$, transferred directly into microwave vessels, and added $5 \mathrm{~mL}$ of concentrated $\mathrm{HNO}_{3}$. The blank solutions, which contain $5 \mathrm{~mL}$ of concentrated $\mathrm{HNO}_{3}$, were also prepared during the analysis of each sample. The analysis of the sample and blank solutions were performed in three replicates and were diluted 10 times with deionized water before analyzed by ICP-MS. The digestion program was chosen in agreement with manufacturer's recommendations, and earlier studies on microwave assisted digestion optimization. Digestion procedure as summarized in Table 2. 
Table 2: Operating conditions for microwave digestion methods.

\begin{tabular}{ll}
\hline Ramp Time & $20 \mathrm{~min}$ \\
Hold Time & $15 \mathrm{~min}$ \\
Temperature & $200{ }^{\circ} \mathrm{C}$ \\
Power & $800 \mathrm{~W}$ \\
\hline
\end{tabular}

\section{RESULTS AND DISCUSSION}

The detection limits, calibration equations were summarized for all elements in Table 3. The calibration curves for all elements were linear within the range from 0.5 to $50 \mu \mathrm{g} / \mathrm{L}$. The detection and quantification limits were calculated over 10 measurements of the blank for microwave procedure, as $3 \mathrm{~s} / \mathrm{b}$ and $10 \mathrm{~s} / \mathrm{b}$, respectively.

Table 3. The detection limits (LOD, $\mu \mathrm{g} / \mathrm{L})$ and typical calibration curves $(\mathbf{n = 1 0})$.

\begin{tabular}{ccccll}
\hline Element & Isotope & LOD $(\boldsymbol{\mu g} / \mathbf{L})$ & LOQ $(\boldsymbol{\mu g} / \mathbf{L})$ & Calibration Equation & $\mathbf{R}^{\mathbf{2}}$ \\
\hline $\mathrm{Al}$ & 27 & 0.233 & $\mathbf{0 . 7 7 7}$ & $\mathrm{y}=22337 \mathrm{x}+15105$ & 0.9974 \\
$\mathrm{~V}$ & 51 & 0.090 & $\mathbf{0 . 3 0 0}$ & $\mathrm{y}=47959 \mathrm{x}+61779$ & 0.9974 \\
$\mathrm{Mn}$ & 55 & 0.032 & $\mathbf{0 . 1 0 7}$ & $\mathrm{y}=67950 \mathrm{x}+72611$ & 0.9986 \\
$\mathrm{Co}$ & 59 & 0.072 & $\mathbf{0 . 2 4 0}$ & $\mathrm{y}=50251 \mathrm{x}+24863$ & 0.9995 \\
$\mathrm{Ni}$ & 60 & 0.070 & $\mathbf{0 . 2 3 3}$ & $\mathrm{y}=11444 \mathrm{x}+6706$ & 0.9951 \\
$\mathrm{Cu}$ & 65 & 0.236 & $\mathbf{0 . 7 8 7}$ & $\mathrm{y}=12050 \mathrm{x}+27863$ & 0.9947 \\
$\mathrm{As}$ & 75 & 0.057 & $\mathbf{0 . 1 9 0}$ & $\mathrm{y}=5967 \mathrm{x}+8573$ & 0.9975 \\
$\mathrm{Mo}$ & 95 & 0.024 & $\mathbf{0 . 0 8 0}$ & $\mathrm{y}=19728 \mathrm{x}+3733$ & 0.9994 \\
$\mathrm{Cr}$ & 52 & 0.012 & $\mathbf{0 . 0 4 0}$ & $\mathrm{y}=110865 \mathrm{x}-70227$ & 0.9976 \\
$\mathrm{Se}$ & 77 & 0.07 & $\mathbf{0 . 2 3 3}$ & $\mathrm{y}=1152 \mathrm{x}+3367$ & 0.9993 \\
\hline
\end{tabular}

The concentrations of heavy metals in the kidney, lung, liver, brain and muscle samples were determined by ICP-MS. All results were presented as miligrams per kilograms. Mean concentrations of elements ( $\mathrm{mg} / \mathrm{kg}$ dry weight) in tissue of cattle were summurized in Table 2. The accuracy of the method was evaluated by comparing with certified values of NIST SRM 2976. The achieved results were in good agreement with certified values. The results for this study were given in Table 3. 
Table 4: The content of heavy metals in the liver, kidney, muscle, and brain in cattle in Sivas, Turkey (mg/kg dry weight, $\mathrm{n}=15)$.

\begin{tabular}{|c|c|c|c|c|c|c|c|c|c|}
\hline & & Al & $\mathbf{v}$ & Mn & $\mathbf{C u}$ & As & Mo & $\mathrm{Cr}$ & Se \\
\hline \multirow[t]{4}{*}{ Kidney } & Minimum & 1.46 & 0.24 & 5.23 & 8.19 & 0.36 & 1.08 & 0.30 & 3.14 \\
\hline & Maximum & 3.11 & 0.53 & 2.73 & 19.46 & 0.57 & 2.72 & 0.67 & 6.01 \\
\hline & Average & 2.40 & 0.35 & 3.95 & 15.82 & 0.47 & 1.87 & 0.47 & 4.38 \\
\hline & $\mathrm{Sd}$ & 0.5 & 0.09 & 0.82 & 3.58 & 0.07 & 0.42 & 0.13 & 0.88 \\
\hline \multirow[t]{4}{*}{ Liver } & Minimum & 1.23 & 0.21 & 1.15 & 205.28 & 0.09 & 2.5 & 0.24 & 0.79 \\
\hline & Maximum & 5.69 & 0.37 & 8.80 & 386.42 & 0.2 & 4.88 & 0.5 & 2.32 \\
\hline & Average & 2.44 & 0.26 & 7.00 & 280.86 & 0.14 & 4.25 & 0.33 & 1.38 \\
\hline & $\mathrm{Sd}$ & 1.06 & 0.04 & 1.8 & 98.49 & 0.03 & 0.64 & 0.07 & 0.45 \\
\hline \multirow[t]{4}{*}{ Lung } & Minimum & 1.58 & 0.21 & 0.48 & 3.01 & 0.07 & 0.2 & 0.26 & 0.30 \\
\hline & Maximum & 5.02 & 0.4 & 1.32 & 16.75 & 0.14 & 2.00 & 0.63 & 1.58 \\
\hline & Average & 3.73 & 0.29 & 0.76 & 7.94 & 0.1 & 1.19 & 0.41 & 0.82 \\
\hline & $\mathrm{Sd}$ & 1.29 & 0.07 & 0.28 & 4.40 & 0.02 & 0.58 & 0.17 & 0.34 \\
\hline \multirow[t]{4}{*}{ Muscle } & Minimum & 1.94 & 0.20 & 0.22 & 1.59 & 0.05 & 0.08 & 0.25 & 0.20 \\
\hline & Maximum & 4.79 & 0.43 & 0.85 & 6.90 & 0.11 & 0.28 & 0.67 & 1.10 \\
\hline & Average & 2.90 & 0.27 & 0.45 & 3.85 & 0.07 & 0.15 & 0.39 & 0.60 \\
\hline & $\mathrm{Sd}$ & 0.90 & 0.06 & 0.17 & 1.64 & 0.02 & 0.05 & 0.10 & 0.25 \\
\hline \multirow[t]{4}{*}{ Brain } & Minimum & 1.69 & 0.22 & 0.85 & 5.66 & 0.02 & 0.19 & 0.12 & 0.27 \\
\hline & Maximum & 5.88 & 0.47 & 1.51 & 14.15 & 0.06 & 0.41 & 0.61 & 0.76 \\
\hline & Average & 3.07 & 0.36 & 1.19 & 10.64 & 0.04 & 0.28 & 0.43 & 0.56 \\
\hline & Sd & 1.52 & 0.07 & 0.29 & 2.85 & 0.01 & 0.08 & 0.13 & 0.17 \\
\hline
\end{tabular}

Sd: standard deviation

Table 5. Trace element concentrations in certified reference material (NIST SRM 2976 muscle tissue ) $\mathrm{n}=3$.

\begin{tabular}{cccc}
\hline Element & Found (mg/kg) & Certified value ( $\mathbf{m g} / \mathbf{k g})$ & Recovery (\%) \\
\hline $\mathrm{Al}$ & $128.0 \pm 6.7$ & $134 \pm 34$ & 96 \\
$\mathrm{Mn}$ & $31.6 \pm 1.3$ & $33 \pm 2$ & 96 \\
$\mathrm{Cu}$ & $3.8 \pm 0.2$ & $4.02 \pm 0.33$ & 95 \\
$\mathrm{As}$ & $12.9 \pm 0.6$ & $13.3 \pm 1.8$ & 97 \\
$\mathrm{Cr}$ & $0.46 \pm 0.01$ & $0.50 \pm 0.16$ & 92 \\
$\mathrm{Se}$ & $1.72 \pm 0.03$ & $1.80 \pm 0.15$ & 95 \\
\hline
\end{tabular}

The results show $\mathrm{Cu}, \mathrm{Mn}$ and Mo to concentrate primarily in the liver; As, V and Se in the kidney, $\mathrm{Al}$ in the lung; $\mathrm{V}$ in the lung and brain. 
$\mathrm{Cu}, \mathrm{Mn}$ and $\mathrm{Cr}$ are an essential trace element that is required for the metabolism. These elements' both the deficiency and excess can cause health problems. Deficiency of Cu can lead to anemia and excess of $\mathrm{Cu}$ causes changes in the color of skin and hair. If an excessive amount of $\mathrm{Cu}$ is taken, the kidney and liver can be damaged. Even the accumulation of excessive $\mathrm{Cu}$ in the liver can cause cirrhosis or hepatitis. Acute poisoning in human for $\mathrm{Cu}$ is $100 \mathrm{mg} / \mathrm{kg}$ as World Health Organization (WHO). According to WHO, copper and manganese are taken 3 and 2-9 mg per daily respectively $\mathrm{Mn}$ and $\mathrm{Cu}$ values have been reported as $15.3-1.2,156-28 \mathrm{mg} / \mathrm{kg}$ in the literature, respectively. The highest $\mathrm{Mn}, \mathrm{Cu}, \mathrm{Mo}$, and concentration were found to be $7.00,280.86,4.25 \mathrm{mg}^{\mathrm{kg}}{ }^{-1}$ respectively. Our $\mathrm{Mn}$ values are in agreement with reported data from the literature. However, our $\mathrm{Cu}$ values are higher than literature values and permissible values of WHO.

Mo values in liver, kidney, and lung are $4.25,1.87,1.19 \mathrm{mg} / \mathrm{kg}$ respectively. Mo values in muscle and brain are lower compared to other tissues. In the literature could not be reached to about Mo levels in animal tissues.

The chromium levels were found $0.12-0.61 \mathrm{mg} / \mathrm{kg}$ in our study. These results are lower compared with literature values and Food and Agriculture Organization (FAO)/WHO limit value which is $1.0 \mathrm{mg} / \mathrm{kg}(22,23)$.

The Al concentration in the lung is relatively higher, compared with the concentration in other tissues. To the best of acknowledging our accumulation of Al in cattle tissue is no information. Selenium is a component of the cytosol enzyme which is glutathione peroxidase and has an important role in intracellular oxidation-reduction reactions. The absorbed Se in the internal organs decreased in the following order: kidney, liver, lung, muscle, and brain in our study. The highest concentration for Se is $4.38 \mathrm{mg} / \mathrm{kg}$ in the kidney.

The levels of $V$ is ranged between $0.26-0.36 \mathrm{mg} / \mathrm{kg}$. This range is narrow when it is compared with other elements in tissue. Our study results showed that there was no significant difference in the concentration of $V$ in all of the tissue of cattle.

As is a non-essential element. It is found that the arsenic accumulates the hair and nail primarily and also liver and kidney in mammals. Most body tissues contain less than 0.3$147 \mathrm{\mu g} / \mathrm{g}$ (dry weight) except for hair, nail, and teeth. As levels in our study ranged between $0.47-0.04 \mathrm{mg} / \mathrm{kg}$ and highest concentration in the kidney as $0.47 \mathrm{mg} / \mathrm{kg}$. Our As values are in agreement with reported data from the literature. 
Distribution of these elements in the organs are related to this specific physiological roles of elements and their relative abundance in intracellular ligands able to bind metals.

\section{ACKNOWLEDGMENTS}

This study has been supported by Cumhuriyet University Scientific Research Projects. Commision as the research Project with the ECZ -005 code.

\section{REFERENCES}

1. Salem AZM, Ammar H, Lopez S, Gohar YM, González JS. Sensitivity of ruminal bacteria isolates of sheep, cattle and buffalo to some heavy metals. Animal Feed Science and Technology [Internet]. 2011;163(2-4):143-9. Available from: http://dx.doi.org/10.1016/j.anifeedsci.2010.10.017

2. Canli M, Atli G. The relationships between heavy metal ( $\mathrm{Cd}, \mathrm{Cr}, \mathrm{Cu}, \mathrm{Fe}, \mathrm{Pb}, \mathrm{Zn}$ ) levels and the size of six Mediterranean fish species. Environmental Pollution. 2003;121(1):129-36.

3. Mendil D, Tuzen M. Assessment of trace elements in animal tissues from Turkey. Environmental Monitoring and Assessment. 2011;182(1-4):423-30.

4. Alonso ML, Benedito JL, Miranda M, Castillo C, Hernández J, Shore RF. Cattle as biomonitors of soil arsenic, copper, and zinc concentrations in Galicia (NW Spain). Archives of Environmental Contamination and Toxicology. 2002;43(1):103-8.

5. Cheng G, He M, Peng H, Hu B. Dithizone modified magnetic nanoparticles for fast and selective solid phase extraction of trace elements in environmental and biological samples prior to their determination by ICP-OES. Talanta [Internet]. 2012;88:507-15. Available from: http://dx.doi.org/10.1016/j.talanta.2011.11.025

6. Reis PA, Almeida CMR. Matrix importance in animal material pre-treatment for metal determination. Food Chemistry. 2008;107(3):1294-9.

7. Milam C, Dimas BJ, Jang AL, Eneche JE. Determination of Some Heavy Metals in Vital Organs of Cows and Bulls at Jimeta Abattoir , Yola, Adamawa State, Nigeria. 2015;8(4):1-7.

8. Jarzyń'ska G, Falandysz J. Selenium and 17 other largely essential and toxic metals in muscle and organ meats of Red Deer (Cervus elaphus) - Consequences to human health.

Environment International. 2011;37(5):882-8.

9. Bagheri H, Afkhami A, Saber-Tehrani M, Khoshsafar H. Preparation and characterization of magnetic nanocomposite of Schiff base/silica/magnetite as a preconcentration phase for the trace determination of heavy metal ions in water, food and biological samples using atomic absorption spectrometry. Talanta [Internet]. 2012;97:87-95. Available from: http://dx.doi.org/10.1016/j.talanta.2012.03.066

10. Besada V, Andrade JM, Schultze F, González JJ. Comparison of the 2000 and 2005 spatial distributions of heavy metals in wild muscles from the North-Atlantic Spanish coast. Ecotoxicology and Environmental Safety. 2011;74(3):373-81.

11. Komarnicki GJK. Tissue, sex and age specific accumulation of heavy metals ( $\mathrm{Zn}, \mathrm{Cu}, \mathrm{Pb}$, Cd) by populations of the mole (Talpa europaea L.) in a central urban area. Chemosphere. 2000;41(10):1593-602. 
12. Frigerio C, Ribeiro DSM, Rodrigues SSM, Abreu VLRG, Barbosa JAC, Prior JA V, et al. Application of quantum dots as analytical tools in automated chemical analysis: A review. Analytica Chimica Acta [Internet]. 2012;735:9-22. Available from: http://dx.doi.org/10.1016/j.aca.2012.04.042

13. Rudy $\mathrm{M}$. The analysis of correlations between the age and the level of bioaccumulation of heavy metals in tissues and the chemical composition of sheep meat from the region in SE Poland. Food and Chemical Toxicology [Internet]. 2009;47(6):1117-22. Available from: http://dx.doi.org/10.1016/j.fct.2009.01.035

14. Shrivas K, Patel DK. Ultrasound assisted-hollow fibre liquid-phase microextraction for the determination of selenium in vegetable and fruit samples by using GF-AAS. Food Chemistry [Internet]. 2011;124(4):1673-7. Available from: http://dx.doi.org/10.1016/j.foodchem.2010.07.054

15. Na P. Concentration of some heavy metals in cattle reared in the vicinity of a metallurgic industry Beáta Koréneková*, Magdaléna Skalická, and Pavel Naï. 2002;72(5):259-67.

16. Okareh OT. Determination of Heavy Metals in Selected Tissues and Organs of Slaughtered Cattle from Akinyele Central Abattoir, Ibadan ,. 2015;5(11):124-9.

17. Lavery TJ, Butterfield N, Kemper CM, Reid RJ, Sanderson K. Metals and selenium in the liver and bone of three dolphin species from South Australia, 1988-2004. Science of the Total Environment. 2008;390(1):77-85.

18. Giussani A. Molybdenum in the Environment and its Relevance for Animal and Human Health. 2011;840-6. Available from:

http://www.sciencedirect.com/science/article/pii/B9780444522726005468

19. Bohrer D, Dessuy MB, Kaizer R, do Nascimento PC, Schetinger MRC, Morsch VM, et al. Tissue digestion for aluminum determination in experimental animal studies. Analytical Biochemistry. 2008;377(2):120-7.

20. Bala A, Suleiman N, Saulawa MA, Danfodiyo U. Detection of Lead (Pb), Cadmium (Cd), Chromium ( $\mathrm{Cr}$ ) Nickel (Ni) and Magnesium Residue in Kidney and Liver of Slaughtered Cattle in Sokoto Central Abattoir, Sokoto State, Nigeria*1. 2013;4(1).

21. Roggeman S, de Boeck G, De Cock H, Blust R, Bervoets L. Accumulation and detoxification of metals and arsenic in tissues of cattle (Bos taurus), and the risks for human consumption. Science of the Total Environment [Internet]. 2014;466-467:175-84. Available from: http://dx.doi.org/10.1016/j.scitotenv.2013.07.007

22. Palmer D, Groppo P. Food Insecurity in the World 2002. 2002;

23. Gordon A. The State of Food Insecurity in the World. 2006. 